\title{
Gm allotypes and HLA in rheumatoid arthritis patients with circulating antibodies to native type II collagen
}

\author{
P A SANDERS, ${ }^{1}$ D M GRENNAN, ${ }^{1}$ P S KLIMIUK, ${ }^{1}$ R B CLAGUE, ${ }^{2}$
} G G deLANGE, ${ }^{3}$ I COLLINS, ${ }^{2}$ P A DYER

From the ${ }^{I}$ University of Manchester Rheumatic Diseases Centre, Hope Hospital, Salford; the ${ }^{2}$ Department of Rheumatology, Withington Hospital, Manchester; the ${ }^{3}$ Central Laboratory of the Netherlands Red Cross Blood Transfusion Service, Amsterdam; and the ${ }^{4}$ Tissue Typing Laboratory, St Mary's Hospital, Manchester

SUMMARY HLA antigens and immunoglobulin heavy chain allotypes $(\mathrm{Gm})$ were determined in 166 unrelated patients with rheumatoid arthritis (RA), 44 of whom had circulating antibodies to native type II collagen. Collagen antibody positive patients showed an association with HLA-DR 3 and DR7 (68\% compared with $39 \%$ of collagen antibody negative RA, p $<0.005)$, and with the $\mathrm{Gm}$ phenotype, Gm(zafngb). This contrasted with the collagen antibody negative RA patients where there was an association with HLA-DR4 and, in DR4 positive disease only, with the $\mathrm{Gm}$ allotype, G1m(x). The Gm(zafngb) phenotype was found in $26 \%$ of DR3 or DR7 positive patients overall and only $9 \%$ of RA patients negative for these DR antigens $(\mathrm{p}<0 \cdot 005)$, suggesting an interaction between HLA-DR3/7 and Gm(zafngb). The differing Gm associations for collagen antibody positive and negative RA provide further evidence for genetic heterogeneity in susceptibility to RA.

Key words: immunoglobulin heavy chain genes, interaction, immunogenetics, heterogeneity of rheumatoid arthritis.

RA is thought to be caused by a combination of genetic and environmental factors. There is a well recorded association between RA and HLA-DR4 in most populations studied ${ }^{1}$ and a weaker association between RA and the immunoglobulin heavy chain constant region allotype, G1m(x), in DR4 positive disease only, suggesting that genes linked to HLA on chromosome 6 and to $\mathrm{Gm}$ on chromosome 14 may interact in disease predisposition. ${ }^{23}$

A subgroup of patients with RA accounting for about $11 \%$ of RA patients seen in hospital has been shown to have circulating antibodies to native type II collagen and shows an association with HLA-DR3 or DR7 rather than DR4. ${ }^{45}$ Apart from a decreased frequency of seropositivity for rheumatoid factor and a later age of disease onset these patients are clinically indistinguishable from those with collagen antibody negative RA. It is uncertain what part the

Accepted for publication I December 19so.

Correspondence to Dr P A Sanders. I Iniversity of Manchester Rheumatic Diseases Centre. Ifope Ilospital. Fecles Old Road. Salford M6 8HD. collagen antibodies play in the pathogenesis of this form of RA. Native type II collagen is the major type of collagen in articular cartilage, ${ }^{6}$ and immunisation of rats and mice with native type II collagen induces a polyarthritis and an immune response. ${ }^{78}$ The results of a single study suggest that the $\mathrm{Gm}$ as well as the HLA associations may differ in collagen antibody positive and negative RA. ${ }^{9}$

The aim of this study therefore was to reinvestigate the relation between RA and $\mathrm{Gm}$ in a larger group of patients who had been tested for the presence of circulating antibodies to native type II collagen and to look for evidence of an interaction between HLA and Gm in this disease subset.

\section{Patients and methods}

One hundred and sixty six patients with classical or definite RA (by American Rheumatism Association criteria $^{10}$ ) were studied. These were all unrelated Caucasians and were attending rheumatology outpatient clinics at Manchester Royal Infirmary 
392 Sanders, Grennan, Klimiuk, Clague, deLange, Collins, Dyer

Table 1 Gm phenotypes in patients with $R A$ and controls

\begin{tabular}{|c|c|c|c|c|c|c|}
\hline \multirow[t]{2}{*}{$\begin{array}{l}\text { Gm } \\
\text { phenotype }\end{array}$} & \multicolumn{2}{|c|}{$\begin{array}{l}\text { Collagen antibody } \\
\text { positive } R A \\
(n=44)\end{array}$} & \multicolumn{2}{|c|}{$\begin{array}{l}\text { Collagen antibody } \\
\text { negative } R A \\
(n=122)\end{array}$} & \multicolumn{2}{|c|}{$\begin{array}{l}\text { Controls } \\
(n=101)\end{array}$} \\
\hline & No & $\%$ & $\mathrm{No}$ & $\%$ & No & $\%$ \\
\hline fnb & 11 & 25.0 & 46 & $37 \cdot 7$ & 34 & $33 \cdot \tilde{c}$ \\
\hline $\mathrm{fb}$ & 3 & $6 \cdot 8$ & 10 & $8 \cdot 2$ & 5 & \\
\hline zaxg & 1 & $2 \cdot 3$ & 8 & $6 \cdot 6$ & 7 & $6.9^{\circ}$ \\
\hline zag & 2 & $4 \cdot 5$ & 5 & $4 \cdot 1$ & 3 & $3 \cdot \bar{e}$ \\
\hline zaxfngb & 5 & 11.4 & 11 & $9 \cdot 0$ & 10 & 9.9 \\
\hline zaxfgb & 2 & $4 \cdot 5$ & 6 & $4 \cdot 9$ & 4 & 4. \\
\hline zafngb & $14^{*}$ & $31 \cdot 8$ & $17^{*}$ & $13 \cdot 9$ & 21 & $20 \cdot 2$ \\
\hline zafgb & 5 & $11 \cdot 4$ & 15 & $12 \cdot 3$ & 15 & 14.ब् \\
\hline Others & 1 & $2 \cdot 3$ & 4 & $3 \cdot 3$ & 2 & \\
\hline
\end{tabular}
patients). The RA group included 35 patients who were selected because they were known to be collagen antibody positive. A control population of 101 volunteer hospital staff unaffected by RA was also included for HLA and Gm typing.

\section{LA BORATORY METHODS}

Serum antibody levels to native type II collagen were measured either by a specific solid phase radioimmunoassay $^{11}$ (MRI patients) or by an enzyme linked immunosorbent assay method (Hope patients) developed from this technique. The normal range was calculated using 15 normal sera with each batch tested (these results did not differ significantly from those obtained using a larger group of 100 normal sera). Results greater than two standard deviations above the mean were considered to be positive.

HLA typing was carried out for A and B antigens using standard National Institute of Health methods. HLA-DR typing was carried out using B lymphocytes isolated by their adherence to nylon wool columns. All antisera were obtained locally or through mutual exchange with other laboratories and characterised using cell panels typed with international histocompatibility antisera.

$\mathrm{Gm}$ and $\mathrm{Km}$ allotyping was performed by the technique of haemagglutination inhibition. ${ }^{12}$ The following allotypes were recognised: $\mathrm{G} 1 \mathrm{~m}(\mathrm{z}, \mathrm{a}, \mathrm{x}, \mathbf{f})$, G2m(n), G3m(b0, b1, b3, b5, g, s, t, c3, c5), Km(1) and (3). G3m (b0, b1, b3, and b5) always occurred together and are henceforth referred to simply as G3m(b).

\section{STA T IS TICS}

Results were analysed using a $\chi^{2}$ test or Fisher's exact test.

Table 1 shows the distribution of Gm phenotypes collagen antibody positive and negative patie groups and in controls. The Gm(zafngb) phenotype was increased in the collagen antibody positive RQ patients when compared with collagen antibody negative RA $(p=0.0093)$. As the phenotyge $\mathrm{Gm}([\mathrm{z}] \mathrm{afgb})$ has been previously reported to 5 associated with collagen antibody positive $\mathrm{RA}^{9}$ inga study in which the $\mathrm{G} 2 \mathrm{~m}(\mathrm{n})$ allotype was not testod for, there is a priori evidence to suggest that phenotypes $\mathrm{Gm}$ (zafngb) or $\mathrm{Gm}$ (zafgb) may implicated in this type of RA so that the $p$ valge need not be corrected for the total number of phenotypes compared. ${ }^{13}$

Table 2 shows the distribution of $\mathrm{Gm}$ and allotypes in the two patient groups and contros. There were no significant differences in frequeney between the groups for $\mathrm{Gm}$ allotypes. $\mathrm{Km}(1)$ was increased in the collagen antibody negative RgA group compared with the controls, but the difference did not reach statistical significance aftr correction of the $p$ value (which is necessary as theree

Table $2 \mathrm{Gm}$ and $\mathrm{Km}$ allotypes in patients with $R A$ and controls

\begin{tabular}{|c|c|c|c|}
\hline $\begin{array}{l}\mathrm{Gm} / \mathrm{Km} \\
\text { allotype }\end{array}$ & $\begin{array}{l}\text { Collagen } \\
\text { antibody } \\
\text { positive } \\
R A(\%) \\
(n=44)\end{array}$ & $\begin{array}{l}\text { Collagen } \\
\text { antibody } \\
\text { negative } \\
R A(\%) \\
(n=122)\end{array}$ & $\begin{array}{l}\text { Controls } \\
(\%) \\
(n=101)\end{array}$ \\
\hline G1m(f) & $90 \cdot 9$ & $88 \cdot 5$ & $89 \cdot 1$ \\
\hline Glm(z) & $68 \cdot 2$ & $54 \cdot 1$ & $60 \cdot 4$ \\
\hline Glm(x) & $18 \cdot 2$ & $22 \cdot 1$ & $21 \cdot 8$ \\
\hline $\mathrm{G} 2 \mathrm{~m}(\mathrm{n})$ & $68 \cdot 2$ & $63 \cdot 1$ & $65 \cdot 3$ \\
\hline $\mathrm{Km}(1)$ & $13 \cdot 6$ & $20 \cdot 5^{*}$ & $9.9^{*}$ \\
\hline
\end{tabular}

${ }^{*} \chi^{2}=4 \cdot 681, p=0 \cdot 031, p_{c}=0.062(\sec t e x t)$. 
Table 3 HLA-DR4, HLA-DR3/7, and Gm(zafngb) in patients with RA and controls

\begin{tabular}{|c|c|c|c|c|c|c|}
\hline \multirow[t]{2}{*}{$H L A / G m$} & \multicolumn{2}{|c|}{$\begin{array}{l}\text { Collagen antibody } \\
\text { positive } R A\end{array}$} & \multicolumn{2}{|c|}{$\begin{array}{l}\text { Collagen antibody } \\
\text { negative } R A\end{array}$} & \multicolumn{2}{|c|}{ Controls } \\
\hline & No & $\%$ & No & $\%$ & No & $\%$ \\
\hline DR3 or DR7* & $28 / 41$ & $68 \cdot 3$ & $44 / 113$ & $38 \cdot 9$ & $49 / 101$ & $48 \cdot 5$ \\
\hline DR4† & $19 / 41$ & $46 \cdot 3$ & $71 / 113$ & $62 \cdot 8$ & $31 / 101$ & $30 \cdot 7$ \\
\hline Gm(zafngb) & $14 / 44$ & $31 \cdot 8$ & $17 / 122$ & $13 \cdot 9$ & $21 / 101$ & $20 \cdot 8$ \\
\hline DR3/7+Gm(zafngb) $\ddagger$ & $10 / 41$ & $24 \cdot 4$ & $9 / 113$ & $8 \cdot 0$ & $9 / 101$ & 8.9 \\
\hline $\mathrm{DR} 4+\mathrm{G} 1 \mathrm{~m}(\mathrm{x}) \S$ & $3 / 41$ & $7 \cdot 3$ & $19 / 113$ & $16 \cdot 8$ & $6 / 101$ & $5 \cdot 9$ \\
\hline
\end{tabular}

${ }^{*}$ Collagen antibody positive RA $v$ antibody negative RA, $\chi^{2}=10.411, p<0.005$.

Collagen antibody positive RA $v$ controls, $\chi^{2}=4 \cdot 600, p<0 \cdot 05$.

†Collagen antibody negative RA $v$ controls, $\chi^{2}=21.084, \mathrm{p}<0.0005$.

$\ddagger$ Collagen antibody positive RA $v$ antibody negative RA, $\chi^{2}=7 \cdot 50, p<0.01$.

Collagen antibody positive RA $v$ controls, $\chi^{2}=5.98, p<0.025$.

$\S$ Collagen antibody negative RA $v$ controls, $\chi^{2}=6 \cdot 11, p<0 \cdot 025$.

is no a priori association of RA with $\mathrm{Km}$ allotypes).

In Table 3 we examine the possibility of an interaction between HLA and Gm in collagen antibody positive RA and show the relative frequencies of HLA-DR4, DR3, and DR7 in the patient groups. As expected there was a strong association between collagen antibody negative RA and HLADR4 and as previously shown an association between RA and G1m(x) bearing haplotypes in DR4 positive disease only. ${ }^{3}$ The collagen antibody positive subgroup was significantly associated with

Table 4 Relative risks (RR) for HLA and Gm markers in $R A$

\begin{tabular}{|c|c|c|c|c|}
\hline \multirow[t]{2}{*}{$H L A / G m$} & \multicolumn{2}{|c|}{$\begin{array}{l}\text { Collagen antibody } \\
\text { positive } R A\end{array}$} & \multicolumn{2}{|c|}{$\begin{array}{l}\text { Collagen antibody } \\
\text { negative } R A\end{array}$} \\
\hline & $R R$ & $\begin{array}{l}95 \% \text { Conf. } \\
\text { limits }\end{array}$ & $R R$ & $\begin{array}{l}95 \% \text { Conf } \\
\text { limits }\end{array}$ \\
\hline DR3/7 & $2 \cdot 24$ & {$[1.65-3.04]$} & 0.66 & {$[0.57-0.77]$} \\
\hline DR4 & 1.95 & {$[1.46-2 \cdot 60]$} & $3 \cdot 82$ & {$[3 \cdot 23-4 \cdot 52]$} \\
\hline Gm(zafngb) & 1.78 & {$[1.28-2 \cdot 47]$} & 0.62 & {$[0.48-0.80]$} \\
\hline G1m(x) & $0 \cdot 80$ & {$[0 \cdot 52-1 \cdot 22]$} & 1.02 & {$[0 \cdot 83-1 \cdot 26]$} \\
\hline \multicolumn{5}{|l|}{ DR $3 / 7+$} \\
\hline Gm(zafngb) & 3.74 & {$[1.94-7.22]$} & 0.58 & {$[0.34-0.99]$} \\
\hline $\mathrm{DR} 4+\mathrm{G} 1 \mathrm{~m}(\mathrm{x})$ & 2.00 & {$[0 \cdot 75-5 \cdot 34]$} & $4 \cdot 62$ & {$[2 \cdot 72-7 \cdot 86]$} \\
\hline
\end{tabular}

Table 5 Interaction between HLA-DR3/7 and $G m$ (zafngb) phenotype frequencies in all patients with $R A$ subdivided according to DR3/7 status

\begin{tabular}{|c|c|c|c|c|}
\hline & \multicolumn{2}{|c|}{$\begin{array}{l}H L A-D R 3+ \\
\text { or } D R 7+\end{array}$} & \multicolumn{2}{|c|}{$\begin{array}{l}H L A-D R 3- \\
\text { and } D R 7-\end{array}$} \\
\hline & No & $\%$ & No & $\%$ \\
\hline Gm(zafngb)+ & $19 / 72$ & $26 \cdot 4$ & $7 / 82$ & $8 \cdot 5$ \\
\hline Gm(zafngb) - & $53 / 72$ & $73 \cdot 6$ & $75 / 82$ & $91 \cdot 5$ \\
\hline
\end{tabular}

$\chi^{2}=8 \cdot 706, p<0.005$.
HLA-DR3 or 7, or both. The combination of DR3 or 7 with the $\mathrm{Gm}$ (zafngb) phenotype was significantly increased in the collagen antibody positive compared with collagen antibody negative patients and controls.

In Table 4 we consider the relative risks for HLA and $\mathrm{Gm}$ linked markers found in association with the respective patient groups. The relative risks for HLA-DR3/7, Gm(zafngb), and the combination of these markers were significantly higher in the collagen antibody positive than in the collagen antibody negative RA group. Although there are trends with this method of analysis for interactions between HLA-DR3/7 or DR4 and the Gm(zafngb) phenotype or $\mathrm{G} 1 \mathrm{~m}(\mathrm{x})$ allotype in collagen antibody positive and negative RA groups respectively, the $95 \%$ confidence limits for the combinations of markers overlapped with those for HLA and Gm linked markers alone.

In the above search for an interaction between HLA and $\mathrm{Gm}$ the numbers of collagen antibody positive patients were relatively small. In Table 5, therefore, we have looked for evidence of an interaction between HLA-DR3/7 and the Gm(zafngb) phenotype in the RA population overall and irrespective of collagen antibody status. As shown there was a statistically significant increase in frequency of this Gm phenotype in DR3 and DR7 positive RA patients.

\section{Discussion}

In previous studies a subgroup of patients with RA characterised by persisting antibodies to native type II collagen was shown to have an HLA association with HLA-DR3 or DR7 rather than with HLADR4, the DR antigen associated with RA patients overall. ${ }^{45}$ The antigens HLA-DR3 and DR7 are in very strong linkage disequilibrium with DQw2. It is 
therefore possible that DQw2 is a better HLA marker for this subset of rheumatoid patients rather than the DR antigens themselves. In the present study we have shown that collagen antibody positive and negative RA subgroups also have different $\mathrm{Gm}$ associations, and these findings are in keeping with those of a previous study of $\mathrm{Gm}$ in collagen antibody positive RA. ${ }^{12}$ These differing associations for HLA and $\mathrm{Gm}$ markers in different RA subgroups add further evidence to a growing concept of genetic heterogeneity in susceptibility to RA (unpublished data). ${ }^{14} 15$

Previous evidence for an interaction between HLA and Gm linked genes has been provided by the demonstration of an increased frequency of the $\mathrm{Gm}$ allotype, $\mathrm{G} 1 \mathrm{~m}(\mathrm{x})$, in DR4 positive but not DR4 negative RA. ${ }^{3}$ In the present study there is a trend for a comparable interaction between genes in linkage disequilibrium with HLA-DR3/7 and Gm in the collagen antibody positive RA subgroup, and this interaction appears statistically significant irrespective of collagen antibody status when the 154 patients typed for HLA and Gm overall are analysed. (This group, however, contained a high percentage of collagen antibody positive patients, and we would not expect to find evidence for an interaction between these HLA and Gm markers in an unselected RA population.) The evidence for an interaction between HLA and Gm linked genes predisposing to RA is in keeping with the findings of previous studies showing that HLA and Gm may interact in influencing humoral responsiveness to bacterial antigens ${ }^{16}$ as well as in predisposing to other autoimmune disorders such as chronic active hepatitis and systemic lupus erythematosus. ${ }^{17} 18$

How 14th and 6th chromosomal genes interact is unknown. One mechanism suggested by a study of collagen induced arthritis in mice is that major histocompatibility complex (MHC) linked genes may regulate the level of overall immunoglobulin synthesis but that non-MHC linked genes (possibly immunoglobulin heavy chain genes) may determine the proportion of this response devoted to a particular autoantibody. ${ }^{19}$ The site of the RA susceptibility gene(s) on the 14th chromosome is similarly uncertain and could be accounted for by immunoglobulin heavy chain constant region genes themselves or by linked $\mathrm{V}$ region genes which map telomeric to those for the immunoglobulin constant region on chromosome $14 .^{20}$

We are grateful to the North West Regional Health Authority for financial support.

\section{References}

1 Stastny P, Association of the B-cell alloantigen DRw4 with rheumatoid arthritis. $N$ Engl J Med 1978; 298: 869-71.
2 Propert D N, Kay P, McCluskey J, Zilko P J, Mathews $\Phi$. Immunoglobulin allotypes in rheumatoid arthritis. In: Dawkinfs R L, Christiansen F T, Zilko P J, eds. Immunogenetics rheumatoid arthritis. Amsterdam: Excerpta Medica, 1983; 315\% 127-9.

3 Sanders P A, deLange G G, Dyer P A, Grennan D M. Gm a d Km allotypes in rheumatoid arthritis. Ann Rheum Dis 1985; 529-32.

4 Dyer P A, Clague R B, Klouda P T, Firth S, Harris R, H $P$ J L. HLA antigens in patients with rheumatoid arthritis and antibodies to native type II collagen. Tissue Antigens 1982; 20: 394-6.

5 Klimiuk P S, Clague R B, Grennan D M, Dyer P A, Smeaton: Harris R. Autoimmunity to native type II collagen-a distinct genetic subset of rheumatoid arthritis. $J$ Rheumatol 1985; 865-70.

6 Miller E J. Isolation and characterization of the cyanogen bromide peptides from the 1(II) chain of chick cartila collagen. Biochemistry 1971; 10: 3030-5.

7 Trentham D E, Townes A S, Kang A H. Autoimmunity of type II collagen: an experimental model of arthritis. J Exp Med 19 E 147: 857-67.

8 Courtenay J S, Dallman M J, Dayan A D, Martin A, Mosedafe B. Immunisation against heterologous type II collagen-induced arthritis in mice. Nature 1980; 283: 666-8.

9 Collier D H, Kerwar S S, Brown R, Stabo J D, Schanfield M\$. Immunoglobulin $\mathrm{G}$ heavy chain $(\mathrm{Gm})$ allotypes and the immure response to types I and II collagen in rheumatoid arthritis. Dहु Markers 1985; 3: 91-102.

10 Ropes M W. Diagnostic criteria for rheumatoid arthritis. 1958 revision. Ann Rheum Dis 1959; 18: 49-53.

11 Clague R B, Firth S A, Holt P J L, Skingle J, Greenbury C里, Webley M. Serum antibodies to type II collagen in rheumatow arthritis: comparison of 6 immunological methods and clinie features. Ann Rheum Dis 1983; 42: 537-44.

12 Van Loghem E. Genetic studies on human immunoglobuli In: Weir D M, ed. Handbook of experimental immunology. 3r ed. Oxford: Blackwell, 1978; I: 11.1-11.16.

13 Svejgaard A, Ryder L P. Associations between HLA and disease. Notes on methodology and a report from the HLA amd disease registry. In: Daussett J, Svejgaard A, eds. HLA a disease. Copenhagen: Munksgaard/Baltimore: Williams \& Wi1kins Co, 1977: 46-53.

14 Grennan D M, Sanders P A, Dyer P A, Harris R. HI⿳亠丷厂 A haplotype sharing by siblings with rheumatoid arthris: evidence for genetic heterogeneity. Ann Rheum Dis 1986; 126-9.

15 Grennan D M, Sanders P A, Dyer P A. Rheumatoid arthri昂: inheritance and association with other auto-immune diseases. Dis Markers 1986; 4: 157-62.

16 Whittingham S, Mathews J D, Schanfield M S, et al. Interactive effect of Gm allotypes and HLA-B locus antigens on the hunn antibody response to a bacterial antigen. Clin Exp Immu间l 1980: 40: 8-15.

17 Whittingham S, Mathews J D, Schanfield M S, Tait B. B Mackay I R. Interaction of HLA and Gm in autongimune chronic active hepatitis. Clin Exp Immunol 1981; $80-6$.

18 Whittingham S, Mathews J D, Schanfield M S, Tait B $\Phi$, Mackay I R. HLA and Gm genes in systemic lupus erythematosus. Tissue Antigens 1983; 21: 50-7.

19 Watson W C, Townes A S. Genetic susceptibility to murg collagen II autoimmune arthritis. Proposed relationship to the IgG2 autoantibody subclass response, complement $\mathrm{C} 5$, major histocompatibility complexes (MHC) and non-MHC loci. J Med 1985; 162: 1878-91.

20 Johnson M J, Natali A M, Cann H M, Honjo T. Cavalli-Sfơ⿱z又, L L. Polymorphisms of a human variable heavy chain gene show linkage with constant heavy chain genes. Proc Natl Acad S్ USA 1984; 81: 7840-4. 